\title{
Sexual Dimorphism Prediction of Darevskia bithynica (Méhely 1909) from Northwestern Anatolia, Turkey by Using Artificial Neural Network
}

\author{
Yapay Sinir Ağı Kullanarak Kuzeybatı Anadolu'dan Darevskia \\ bithynica ‘nın (Méhely 1909) Cinsiyet Dimorfizmi Tahmini
}

\author{
Research Article
}

Çağın Kandemir Çavaş ${ }^{*}$, Yusuf Kumlutaş ${ }^{2}, K^{\prime}$ amil Candan², Çetin Ilgaz ${ }^{2 *}$

'Dokuz Eylül University, Faculty of Sciences, Department of Computer Science, Buca, Izmir, Turkey.

${ }^{2}$ Dokuz Eylül University, Faculty of Sciences, Department of Biology, Buca, İzmir, Turkey.

\section{A B S TR ACT}

\begin{abstract}
The aim of the study is to predict the gender of Darevskia bithynica by using a feed-forward back-propagation artificial neural network (ANN). Nine morphological characters were used as an input parameters of the model. The gender type male or female is the output parameter. The total number of data is 115 . In order to train, validate and test the ANN model $70 \%, 15 \%$ and $15 \%$ of the total data are randomly selected, respectively. The regression coefficient $(R)$ values are evaluated as prediction performance. The network's layer with tangent sigmoid activation functions predicts the lizard gender with $\mathrm{R}$ values as $0.98,0.97$ and 0.96 for training, testing and all data, respectively. The mean square error (MSE) values for training and testing data are calculated as 0.0145 and 0.0161 , respectively. The obtained results satisfactorily confirm the high ability of the ANNs in predicting the gender of Darevskia bithynica.
\end{abstract}

\section{Key Words}

Artificial neural network, sexual dimorphism, Darevskia bithynica, Northwestern Anatolia.

\section{öz}

\begin{abstract}
Calışmanın amacı ileri beslemeli geri yayılımlı yapay sinir ağı (YSA) kullanarak Darevskia bithynica 'nın cin5 siyetini tahmin etmektir. Modelin girdi parametreleri olarak dokuz morfolojik karakter kullanılmıştır. Erkek veya dişi cinsiyet tipi, çıktı parametresidir. Toplam veri sayısı 115'dir. YSA modelini eğitmek, doğrulamak ve test etmek için sırasıyla toplam verilerin \%70'i, \%15'i ve \%15'i rasgele seçilir. Tahmin performansı olarak regresyon katsayısı değerleri (R) ele alınmıştır. Tanjant sigmoid aktivasyon fonksiyonlarına sahip ağ, sırasıyla eğitim, test ve tüm veriler için $R$ değeri ile kertenkele cinsiyetini 0.98, 0.97 ve 0.96 olarak tahmin etmektedir. Eğitim ve test verileri için hata kareler ortalaması değerleri (HKO) sırasıyla 0.0145 ve 0.0161 olarak hesaplanmıştır. Elde edilen sonuçlar, YSA'lerin Darevskia bithynica 'nın cinsiyetini tahmin etme yeterliğini memnun edici bir şekilde desteklemektedir.
\end{abstract}

Anahtar Kelimeler

Yapay sinir ağı, cinsiyet dimorfizmi, Darevskia bithynica, Kuzeybatı Anadolu.

Article History: Received: Oct 8, 2017; Revised: Jun 24, 2018; Accepted: Sep 28, 2018; Available Online: Nov 13, 2018. DOI: $10.15671 /$ HJBC.2018.255

Correspondence to: Ç. Kandemir Çavaş, Department of Computer Science, Dokuz Eylül University, Izmir, Turkey. 


\section{INTRODUCTION}

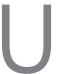
ntil recently, Darevskia bithynica was being considered a subspecies of Darevskia rudis [1, 2]. In the study by Arribas et al. [3], lizard specimens from north-west of Anatolia were examined for external morphology and osteology and $D$. bithynica was raised to species rank, with two subspecies: D. b. bithynica and D. b. tristis. D. bithynica is a small lacertid with length approximately up to $75 \mathrm{~mm}$. It lives mostly on rock exposures, uses crevices as refuges, and prefers habitats in and around herbaceous vegetation [3].

Artificial neural networks (ANNs) is one of the machine learning techniques that offer robust and significant result in scientific studies, especially in order to make classification, clustering, vector quantization, pattern association, function approximation. Although all these analyses can be experimentally performed, using ANNs are very time-saving, rapid, robust and efficient [4-6]. Up to now, no detailed information has been reported on morphological differences between males and females in $D$. bithynica. The main aim of the present paper is to predict the sexual dimorphism of Darevskia bithynica by using a feed-forward back-propagation multilayer artificial neural network (ANN). According to the literature search, no published material existed on the application of ANN on the prediction of sexual dimorphism.

\section{MATERIALS and METHODS \\ Data Set}

One hundred fifteen of $D$. bithynica $\left(670^{\lambda} \delta^{\lambda}\right.$ and 48\%O), deposited in the Fauna and Flora Research and Application Centre of Dokuz Eylül University (Buca-Izmir) were examined. Animals were captured in NW Turkey in mid April 2009 from 11 different localities (from sea level to at altitudes of $1720 \mathrm{~m}$ a.s.I.) (Table 1). Only adults (snout-vent length greater than $50 \mathrm{~mm}$ ) were included in the analyses. The specimens were fixed with $96 \%$ ethanol and then preserved in $70 \%$ ethanol until their examination according to the method described by [7]. To quantify sexual size dimorphism (SSD) in the populations studied, we measured nine biometric characters: Snout-vent length (SVL-Tip of snout to anal cleft); Pileus width (PW-At the widest point between the parietal plates); Pileus length (PL-Tip of snout to posterior margins of parietals); Head width (HWAt the widest point of head, from cheek to cheek); Head length (HL-Tip of snout to posterior margin of ear opening); Forelimb length (FLL-Shoulder joint to tip of toe); Hindlimb length (HLL-Pelvic joint to tip of toe); Anal wide (AW) and Anal length

Table 1. Geographic details of the localities in which specimens were collected in northwestern Anatolia, Turkey.

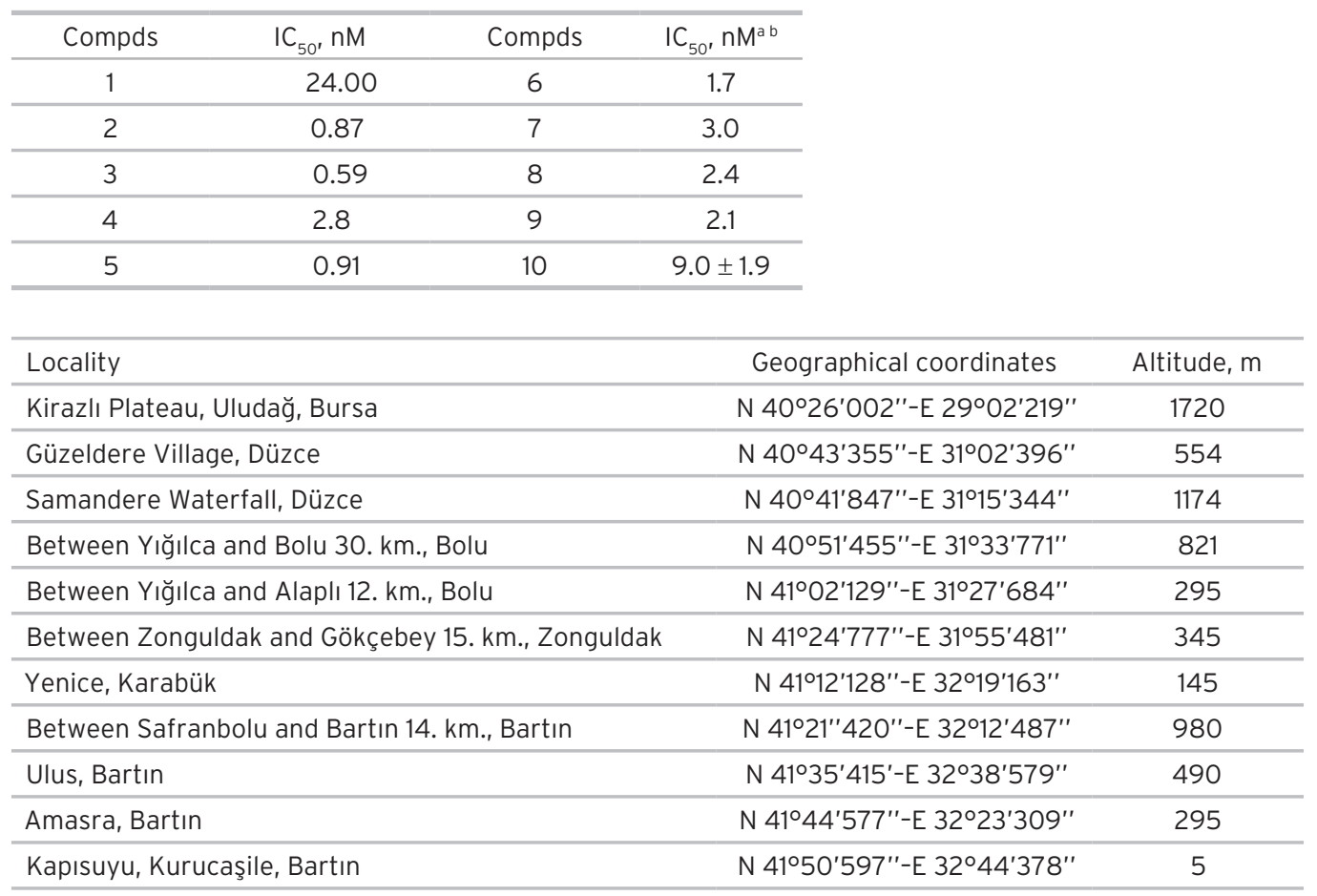




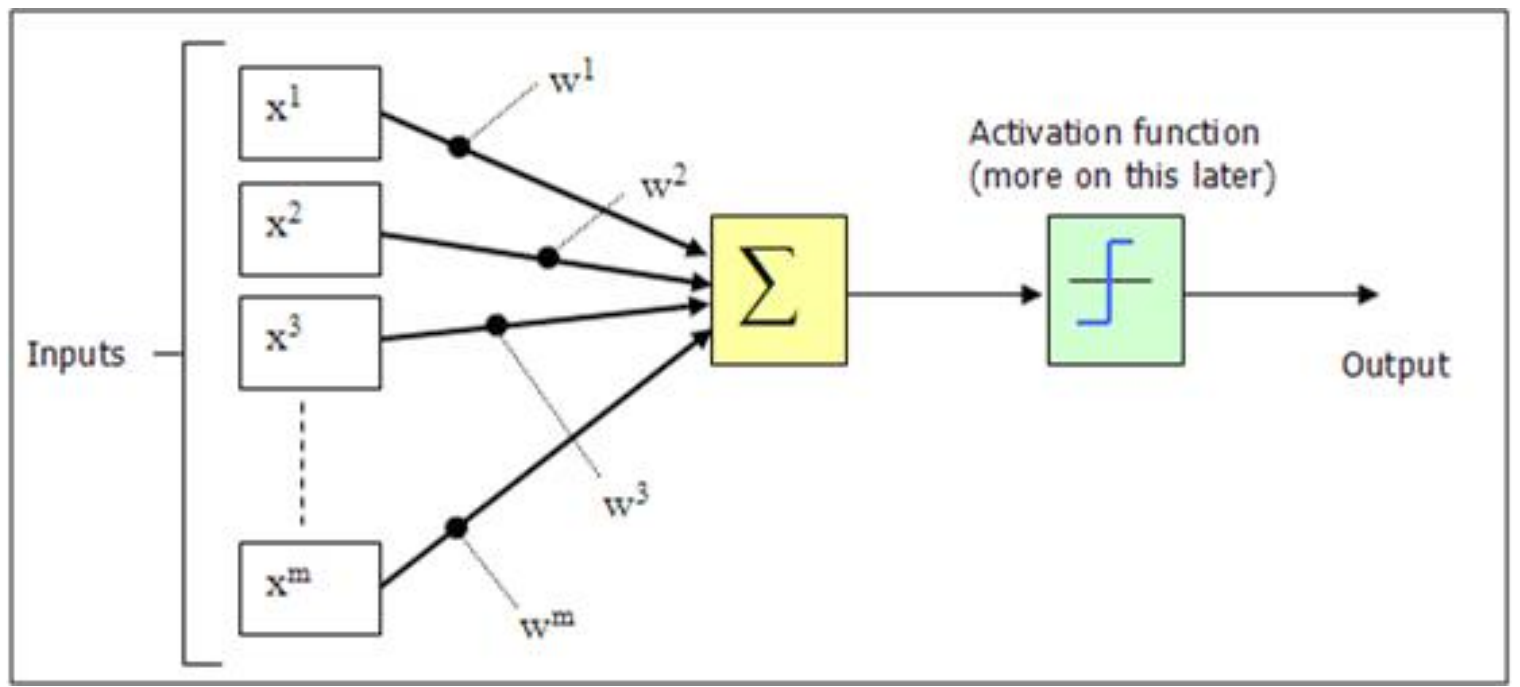

Figure 1. A general artificial neuron model.

$(A L)$. All linear measurements were made with a digital caliper to the nearest $0.01 \mathrm{~mm}$. In order to identify sex, we used the presence/ absence of hemipenes that are retracted in hemipenial sacks at the base of the tail. In order to determine for descriptive statistic of the specimens, SPSS 16.0 statistical packages program were used.

\section{RESULTS AND DISCUSSION Modelling}

Artificial neural network (ANN) is a system that resembles the organizational principles of the human brain. Therefore, an ANN is able to learn, generalize behaviors after training processes [8]. ANN structure reflects biological neurons of a brain that is illustrated in Figure 1.

Figure 1 shows that the given input data can be transferred to the artificial neuron model and the output can be obtained as the signal which is transformed to the information in the biological neuron. $\sum$ denotes the weighted input or NET input which are explained in following sections, $x^{1}, \ldots, x^{m}$ are the input data, $w^{1}, \ldots, w^{m}$ are the weights, activation function of a node defines the output of that node given an input or set of inputs.

\section{Feed-forward Back-propagation Multilayer Artificial Neural Network}

In order to solve the limitations of one-layer networks i.e. classifying nonlinearly problems and to use in many applications, feed forward multilayer networks are proposed.
Backpropagation algorithm is the generalized technique of the least mean square to minimize the error between the actual and the desired output of the neural network. The network is supervisory trained for the input-output pairs. After the training process is completed, the network weights are used to obtain output values of the new input data. At first, the defined input data in the input layer are multiplied by the weights and the sum is called as NET input as follows,

$$
\text { NET input }=\sum_{i=1}^{p} x_{i} w_{j i}
$$

The output of the hidden layer, $u_{j}$ where $j=1, \ldots, L$, is the input values of the output layers. Therefore, the output values of the hidden layer is equal of activation function of NET input as follows,

$$
f(\text { NET input })=u_{j}=f\left(\sum_{i=1}^{p} x_{i} w_{j i}\right)
$$

The whole steps of the backpropagation algorithm of the $\mathrm{p}^{\text {th }}$ pattern in a feedforward network [9] can be given as,

1. Let $x_{p, i}$ denote the value of the $\mathrm{i}^{\text {th }}$ node for the $\mathrm{p}^{\text {th }}$ pattern in the input layer.

2. NET input of the $j^{\text {th }}$ node in the hidden layer

$$
n e t_{j}^{(1)}=\sum_{i=0}^{n} w_{j, i}^{(1,0)} x_{p, i}
$$


where $w_{i, i}^{(1,0)}$ is the weight between the $i^{\text {th }}$ input layer node to the $\mathrm{j}^{\text {th }}$ hidden layer node.

3. The output of the $\mathrm{j}^{\text {th }}$ node in the hidden layer

$$
x_{p, j}^{(1)}=\delta\left(\sum_{i=0}^{n} w_{j, i}^{(1,0)} x_{p, j}^{(1)}\right)
$$

where $\delta$ is the sigmoid activation function.

4. The NET input of the $k^{\text {th }}$ node in the output layer

$$
n e t_{k}^{(2)}=\sum_{j}\left(w_{k, j}^{(2,1)} x_{p, j}^{(1)}\right)
$$

where $w_{k, j}^{(2,1)}$ is the weight between the $\mathrm{j}^{\text {th }}$ hidden layer node to the $k^{\text {th }}$ output layer node.

5. Output of the $k^{\text {th }}$ node of the output layer

$$
y_{p, k}=\delta\left(\sum_{j} w_{k, j}^{(2,1)} x_{p, j}^{(1)}\right)
$$

where $\delta$ denotes the sigmoid activation function.

6. Finally the squared error can be calculated as

$$
\varepsilon_{p, k}^{2}=\left|d_{p, k}-y_{p, k}\right|^{2}
$$

where $d_{p, k}$ is the desired output and $y_{p, k}$ is the actual output.

The aim of the algorithm is to obtain appropriate weights in order to minimize error $E_{p}$ for pattern

$p$, where it is expressed as follows,

$$
E_{p}=\sum_{k}\left(\varepsilon_{p, k}\right)^{2}
$$

The above equation can write as

$$
E=\sum_{k=1}^{K}\left(\varepsilon_{k}\right)^{2}
$$

Gradient descent method can be used to minimize E.

Gradient descent algorithm says that updating value of the weights $w$ can be expressed as $-\partial E / \partial w$.

Modification of the weight for the connection between input layer and hidden layer can be expressed as

$$
\Delta w_{j, i}^{(1,0)} \propto\left(\frac{-\partial E}{\partial w_{j, i}^{(1,0)}}\right)
$$

Modification of the weight for the connection between hidden layer and output layer can be expressed as

$$
\Delta w_{k, j}^{(2,1)} \propto\left(\frac{-\partial E}{\partial w_{k, j}^{(2,1)}}\right)
$$

The derivative of $E$ with respect to $y_{j}$ is calculated in order to calculate the effect of the error on the output.

$\frac{\partial E}{\partial y_{j}}=-2\left(d_{k}-y_{k}\right)$

In order to calculate the effect of the output on the activation

$$
\frac{\partial y_{j}}{\partial w_{j, i}}=\frac{\partial y_{j}}{\partial(\mathrm{NET} \text { input })} \frac{\partial(\mathrm{NET} \text { input })}{\partial w_{j, i}}=y_{j}\left(1-y_{j}\right) x_{j}
$$

Then,

$\frac{\partial E}{\partial w_{j, i}}=\frac{\partial E}{\partial y_{j}} \frac{\partial y_{j}}{\partial w_{j, i}}=2\left(d_{j}-y_{j}\right) y_{j}\left(1-y_{j}\right) x_{j}$

Finally, the updating can be defined as,

$$
\Delta w_{j, i}=-2 \eta\left(d_{j}-y_{j}\right) y_{j}\left(1-y_{j}\right) x_{i}
$$

\section{RESULTS and DISCUSSION}

The descriptive statistics including minimum, maximum, mean, standard deviation and standard error of the mean for each sex are given in Table 2. The males examined in the present study had larger values than the females according to all morphological characters that are used in the analyses (Table 2).

The ANN model was developed using the neural network toolbox in MATLAB R2010a. A multilayer feed-forward network based on the back-propagation learning algorithm is used to predict the gender of Darevskia bithynica using sexual size measurements. The total number of lizard samples was $115.70 \%, 15 \%$ and $15 \%$ of the total data were used as training, validation and testing, respectively. The architecture of the model is shown in Figure 2.

The prediction model consists of one input, one hidden and one output layers. Nine sexual size measurements: $\mathrm{SVL}, \mathrm{PL}, \mathrm{PW}, \mathrm{HW}, \mathrm{HL}, \mathrm{FLL}$, $H L L, A W$ and $A L$ are used as input variables of the input layer. The gender whether male or female 
Table 2. Descriptive statistics of morphological characters of males and females in Darevskia bithynica. For abbreviations, see the text; $\mathrm{N}$, the number of specimens; Min, minimum value; Max, maximum value; SD, standard deviation, $\mathrm{SE}$, standard error of the mean.

\begin{tabular}{|c|c|c|c|c|c|c|c|c|c|c|c|c|}
\hline \multicolumn{8}{|c|}{$\hat{\partial O}$} & \multicolumn{5}{|c|}{ 우우 } \\
\hline Characters & $\mathrm{N}$ & Mean & Min. & Max. & SD & SE & $\mathrm{N}$ & Mean & Min. & Max. & SD & SE \\
\hline SVL & 67 & 63.65 & 52.38 & 72.84 & 3.53 & 0.43 & 48 & 62.33 & 50.94 & 73.42 & 5.36 & 0.77 \\
\hline PW & 67 & 7.32 & 5.80 & 8.34 & 0.58 & 0.07 & 48 & 6.20 & 5.30 & 7.30 & 0.43 & 0.06 \\
\hline PL & 67 & 15.54 & 12.78 & 17.12 & 0.86 & 0.10 & 48 & 12.91 & 11.18 & 14.74 & 0.89 & 0.13 \\
\hline HW & 67 & 9.20 & 6.76 & 10.84 & 0.79 & 0.10 & 48 & 7.31 & 4.34 & 8.60 & 0.76 & 0.11 \\
\hline $\mathrm{HL}$ & 67 & 21.56 & 2.76 & 24.82 & 2.65 & 0.32 & 48 & 18.70 & 16.52 & 21.50 & 1.47 & 0.21 \\
\hline FLL & 67 & 22.23 & 18.44 & 26.00 & 1.41 & 0.17 & 48 & 18.92 & 16.74 & 21.30 & 1.33 & 0.19 \\
\hline HLL & 67 & 34.22 & 28.78 & 38.80 & 2.21 & 0.27 & 48 & 29.23 & 24.48 & 36.46 & 2.55 & 0.37 \\
\hline AW & 67 & 2.24 & 1.50 & 3.12 & 0.25 & 0.03 & 48 & 2.19 & 1.82 & 2.88 & 0.26 & 0.04 \\
\hline$A L$ & 67 & 4.85 & 3.88 & 7.34 & 0.57 & 0.07 & 48 & 4.24 & 2.02 & 5.00 & 0.53 & 0.08 \\
\hline
\end{tabular}

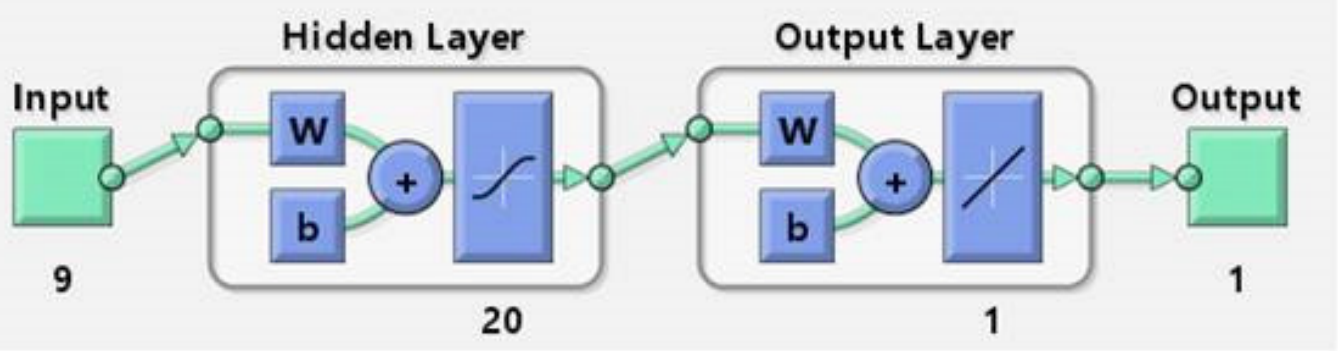

Figure 2. The architecture of the neural network model.

is the output variable of the output layer. The ANN had one hidden layer with 20 neurons that gives the best results. The activation function for the layers is tangent sigmoid. The LevenbergMarquardt optimization algorithm was used in the training process. The Levenberg-Marquardt algorithm is a method to solve nonlinear least squares problems $[10,11]$. The performance of the model can be evaluated by two parameters: The first one is the regression coefficient $(R)$ that measures the correlation between actual and predicted values for the training, testing and all data as seen in Figure 3. The related results can be referred as strong relationship exist between predicted and actual values whenever they are above 0.9. The second one is the mean squared error (MSE) as seen in Table 3 that measures the average squared difference between actual and predicted values. The lower MSE value is expressed as better prediction performance for the ANN. For the training and testing data, MSE is obtained as 0.0145 and 0.0161 , respectively.

Lizards are good model for the study of the evolution of sexual dimorphism $[12,13]$. Sexual dimorphism is a common phenomenon among lizard species [14-20]. Darevskia bithynica is sexually dimorphic in body size and shape. Males have larger values related to all characters examined in the present study than females. Sexual dimorphism in body size and shape occurs in several congeneric species $[13,21-30]$.

In lacertid lizard, males generally have a relatively longer snout-vent length (SVL) than females and males have generally relatively larger heads compared to females [21,31]. Males with bigger heads have advantages in intersexual interactions $[32,24]$. In courtship, males having larger heads succeed in grasping a female faster than males having smaller heads and can successfully grasp and hold a female [21,33]. Also males are being able to eat larger prey than females $[34,35]$.

\section{CONCLUSIONS}

In the present study, the feed-forward backpropagation multilayer ANN model gives very satisfactory results to predict the gender of Darevskia bithynica by using its morphometric measurements. Optimal ANN structure is obtained as one input, one hidden with 20 neurons and one 

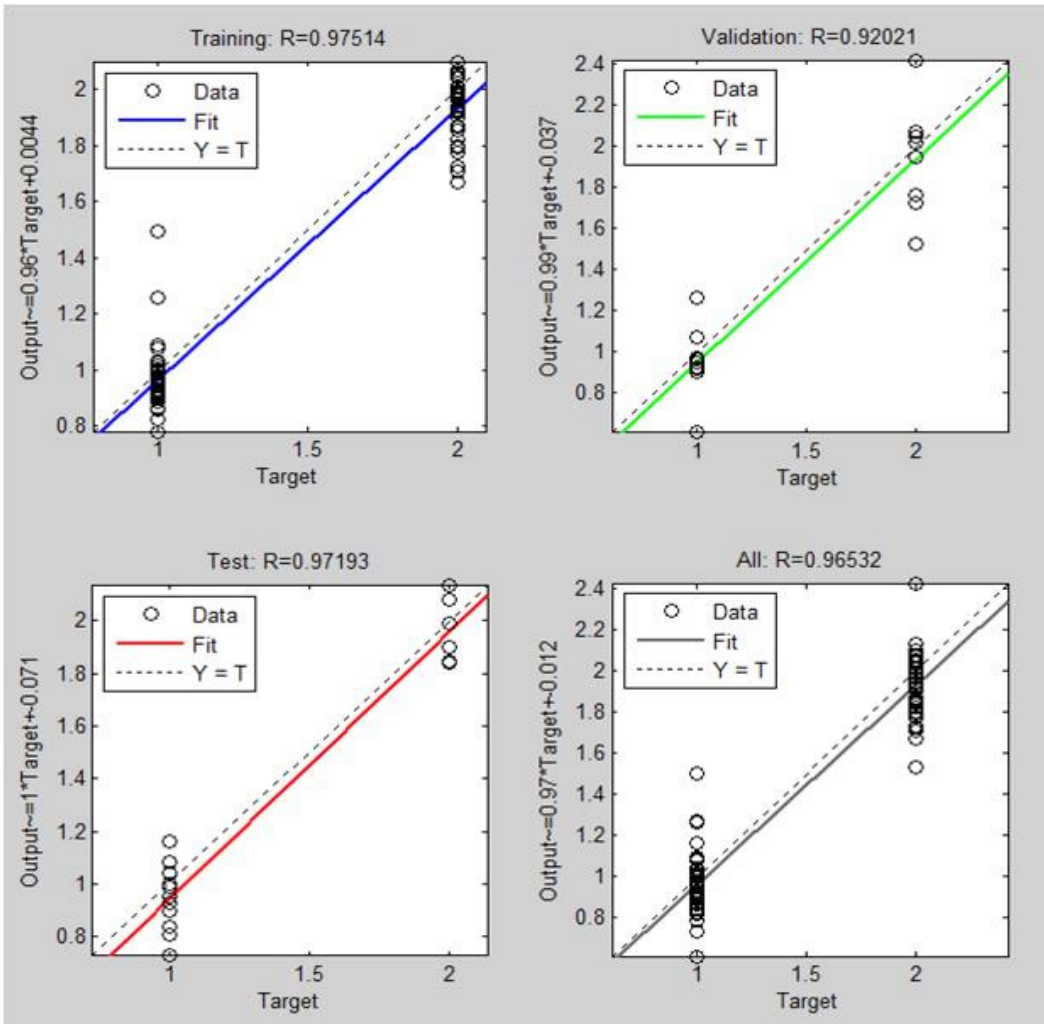

Figure 3. Output of program for the performance of training, validation and testing of ANN model.

Table 3. Mean square error (MSE) values for training, validation and testing processes.

\begin{tabular}{ccc} 
& Samples & MSE \\
\hline Training & 81 & 0.0145 \\
Validation & 17 & 0.0697 \\
Testing & 17 & 0.0161 \\
\hline
\end{tabular}

output layer. The activation function is identified as tangent sigmoid function. The total data set is divided three parts for training, validation and test sets which contains $70 \%, 15 \%$ and $15 \%$ of data samples, respectively. The R and MSE values for actual and predicted genders are obtained as 0.97 and 0.0161 for testing, respectively. The results are strongly established that ANN model can be used on predicting the gender of Darevskia bithynica based on their sexual size measurements.

\section{Acknowledgments}

Lizard samples were collected by the financial support of Research Council (BAP) Dokuz Eylül University under project number 2009.KB.FEN.003. 


\section{References}

1. J. Eiselt, IS. Darevsky, Lacerta rudis chechenica ssp. n. aus dem Kaukasus (Reptilia: Lacertidae), Ann. Nat. Hist. Mus. Wien, 92 (1991) 15-29. http://www.zobodat. at/pdf/ANNA_92B_0015-0029.pdf

2. i. Baran, Ç. Ilgaz, A. Avcl, Y. Kumlutaş, K. Olgun, Türkiye Amfibi ve Sürüngenleri [The Amphibians and Reptiles of Turkey], TÜBiTAK Popüler Bilim Kitapları, Ankara, (2012).

3. O. Arribas, Ç. Ilgaz, Y. Kumlutaş, SH. Durmuş, A. Avcl, N. Üzüm, External morphology and osteology of Darevskia rudis (Bedriaga, 1886), with a taxonomic revision of the Pontic and Small-Caucasus populations (Squamata: Lacertidae), Zootaxa, 3626 (2013) 401428. http://www.lacerta.de/AS/Bibliografie/BIB_7417. $\mathrm{pdf}$

4. MH. Hassoun, Fundamentals of Artificial Neural Networks, MIT Press, London, (1995).

5. W. Bouzid, S. Lek, M. Mace, O. Ben Hassine, R. Etienne, L. Legal, G. Loot, Genetic diversity of Ligula intestinalis (Cestoda: Diphyllobothriidea) based on analysis of inter-simple sequence repeat markers, J. Zool. Syst. Evol. Res., 46 (2008) 289-296. http://onlinelibrary. wiley.com/doi/10.1111/j.1439-0469.2008.00471.x/ epdf

6. P.A. Khara, S.V. Dudul, Epilepsy diagnosis based on generalized feed forward neural network, Interdiscip. Sci., 4 (2012) 209-214.

7. M. Başoğlu, i. Baran, Türkiye Sürüngenleri, Kısım I, Kaplumbağa ve Kertenkeleler. [The Reptiles of Turkey Part I. The Turtles], Ege Üniversitesi Fen Fakültesi Kitaplar Serisi, Bornova, İzmir, (1977).

8. C.T. Lin, C.S.G. Lee, Neural Fuzzy Systems, A NeuroFuzzy Synergism to Intelligent Systems, Prentice Hall, New Jersey, (1996).

9. K. Mehrotra, C.K. Mohan, S. Ranka, Elements of Artificial Neural Network, MIT Press, USA, (2000).

10. K. Levenberg, A method for the solution of certain non-linear problems in least squares, Q. Appl. Math. 2 (1944) 164-168.

11. D. Marquardt, An algorithm for least-squares estimation of nonlinear parameters. SIAM J. AppI. Math., 11 (1963) 431-441.

12. R.M. Cox, S.L. Skelly, H.B. John-Alder, A comparative test of adaptive hypotheses for sexual size dimorphism in lizards, Evol., 57 (2003) 1653-1669.

13. A. Kaliontzopoulou, M.A. Carretero, G.A. Llorente, Head shape allometry and proximate causes of head sexual dimorphism in Podarcis lizards: joining linear and geometric morphometrics, Biol. J. Linn. Soc., 93 (2007) 111-124.

14. T.W. Schoener, The ecological significance of sexual dimorphism in size in the lizard Anolis conspersus, Science 155 (1967) 474-477.

15. H.S. Fitch, Sexual size differences in reptiles, Miscellaneous Publications of the University of Kansas Museum of Natural History. Lawrence K.S, University of Kansas Museum of Natural History, (1981).
16. J. Stamps, Sexual size dimorphism in species with asymptotic growth after maturity, Biol. J. Linn. Soc., 50 (1993) 123-145.

17. J.H. Carothers, Sexual selection and sexual dimorphism in some herbivorous lizards, Am. Nat., 124 (1984) 244-254.

18. L.J. Vitt, W.E. Cooper, The evolution of sexual dimorphism in the skink Eumeces laticeps: an example of sexual selection, Can. J. Zool., 63 (1985) 995-1002.

19. J.L. Vial, J.R. Stewart, The manifestation and significance of sexual dimorphism in anguid lizards: a case study of Barisia monticola, Can. J. Zool., 67 (1989) 68-72.

20. P.F.N. Mouton, J.H. Vanwyk, Sexual dimorphism in cordylid lizards: a case study of the Drakensberg crag lizard, Pseudocordylus melanotus. Can. J. Zool., 71 (1993) 1715-1723.

21. F. Braña, Sexual dimorphism in lacertid lizards: male head increase vs female abdomen increase, Oikos, 75 (1996) 511-523.

22. E.J. Censky, Mating strategy and reproductive success in the teiid lizard Ameiva plei, Behaviour, 132 (1995) 529-557.

23. L. Gvozdik, M. Boukal, Sexual dimorphism and intersexual food niche overlap in the sand lizard, Lacerta agilis (Squamata, Lacertidae), Folia Zool., 47 (1998) 189-195.

24. L. Gvozdik, R. van Damme, Evolutionary maintenance of sexual dimorphism in head size in the lizard Zootoca vivipara: a test of two hypotheses, J. Zool., 259 (2003) 7-13.

25. A. Herrel, R. Spithoven, R. van Damme, F. de Vree, Sexual dimorphism of head size in Gallotia galloti: testing the niche divergence hypothesis by functional analyses, Funct. Ecol., 13 (2002) 289-297.

26. E.S. Roitberg, Variation in sexual size dimorphism within a widespread lizard species. in: D.L. Fairbrain, W.U Blackenhorn and T. Székely (eds.), Sex, Size, and Gender Roles. Evolutionary Studies of Sexual Size Dimorphism, Oxford University Press, Oxford, pp. 143-217 (2007).

27. H. Oraie, H. Rahimian, N. Rastegar-Pouyani, A. Khosravani, E. Rastegar-Pouyani, Sexual size dimorphism in Ophisops elegans (Squamata: Lacertidae) in Iran, Zool. Middle East, 59 (2013) 302307.

28. A. Dehghani, S.S. Hosseinian Yousefkhani, N. RastegarPouyani, MH. A. Banan-Khojasteh Mohammadpour, Sexual size dimorphism in Darevskia raddei (Sauria: Lacertidae) from northwestern Iran, Zool. Middle East, 60 (2014) 120-124.

29. A.M. Castilla, D. Bauwens, E.R. van Dam, R. Verheyen, Notes on the biology of the high altitude lizard Lacerta bedriagae, J. Herpetol., 1 (1989) 400-403.

30. M. Molina-Borja, M. Padron-Fumero, M.T. Al-FonsoMartin, Intrapopulation variability in morphology, coloration, and body size in two races of the lacertid lizard, Gallotia galloti, J. Herpetol., 31, (1997) 499-507. 
31. O. Arribas, Taxonomic revision of the Iberian 'Archaeolacertae' I: A new interpretation of the geographical variation of 'Lacerta' monticola Boulenger, 1905 and 'Lacerta' cyreni Müller \& Hellmich, 1937 (Squamata: Sauria: Lacertidae), Herpetozoa, 9 (1996) 31-56.

32. C.M. Bull, Y. Pamula, Sexually dimorphic head size and reproductive success in the sleepy lizard Tiliqua rugose, J. Zool., 240 (1996) 511-521.

33. A. Herrel, R. van Damme, F. de Vree, Sexual dimorphism of the head size in Podarcis hispanica atrata: testing the dietary divergence hypothesis by bite force analysis, Neth. J. Zool., 46 (1996) 253-262.
34. M.R. Preest, Sexual size dimorphism and feeding energetics in Anolis carolinensis. Why do females take smaller prey than males? J. Herpetol., 28 (1994) 292-298.

35. T.W. Schoener, Competition and the niche. in: C. Gans and D. W. Tinkle (eds.), Biology of the Reptilia, Volume 7: Ecology and Behaviour, Academic Press, London, p. 135-136, (1977). 